\title{
Association of coffee drinking with all-cause mortality: a systematic review and meta-analysis
}

\author{
Yimin Zhao ${ }^{1,2}$, Kejian Wu ${ }^{1,2}$, Jusheng Zheng ${ }^{1,2}$, Ruiting Zuo ${ }^{1,2}$ and Duo $\mathrm{Li}^{1,2, *}$ \\ 'Department of Food Science and Nutrition, Zhejiang University, 866 Yuhangtang Road, Hangzhou 310058 , \\ People's Republic of China: ${ }^{2}$ APCNS Centre of Nutrition and Food Safety, Hangzhou, People's Republic of China
}

Submitted 9 February 2014: Final revision received 6 June 2014: Accepted 12 June 2014: First published online 4 August 2014

\begin{abstract}
Objective: We aimed to use the meta-analysis method to assess the relationship between coffee drinking and all-cause mortality.

Design: Categorical and dose-response meta-analyses were conducted using random-effects models.

Setting: We systematically searched and identified eligible literature in the PubMed and Scopus databases.

Subjects: Seventeen studies including 1054571 participants and 131212 death events from all causes were included in the present study.

Results: Seventeen studies were included and evaluated in the meta-analysis. A U-shaped dose-response relationship was found between coffee consumption and all-cause mortality ( $P$ for non-linearity < 0 001). Compared with non/occasional coffee drinkers, the relative risks for all-cause mortality were 0.89 (95\% CI $0.85,0.93)$ for $1-<3$ cups/d, 0.87 (95\% CI 0.83, 0.91) for $3-<5$ cups/d and 0.90 (95\% CI 0.87, 0.94) for $\geq 5 \mathrm{cups} / \mathrm{d}$, and the relationship was more marked in females than in males. Conclusions: The present meta-analysis of prospective cohort studies indicated that light to moderate coffee intake is associated with a reduced risk of death from all causes, particularly in women.
\end{abstract}

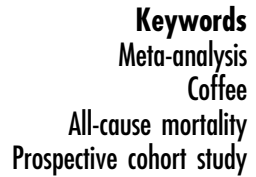

Coffee is one of the most popular beverages in the world and the health-related effects of coffee have been frequently studied. Habitual coffee drinking was reported to be inversely related to the risks of type 2 diabetes $^{(1)}$ and chronic liver disease ${ }^{(2)}$. As a major dietary source of antioxidants, coffee may also help to improve the resistance of LDL to oxidation and reduce oxidative DNA damage ${ }^{(3)}$.

Results from prospective cohort studies regarding the association of habitual coffee drinking with all-cause mortality were inconclusive ${ }^{(4-6)}$. O'Keefe et $a l^{(7)}$ recommended that moderate intake of coffee, tending towards two or three to as many as four cups daily, would be a better choice for keeping healthy rather than excessive coffee consumption. Besides, the association of coffee intake with all-cause mortality may differ between men and women. Lopez-Garcia et $a l^{(8)}$ observed that the significant inverse association of coffee drinking with total mortality was attenuated in men when compared with that in women. Similar results were also found in another large cohort study ${ }^{(9)}$. A recent meta-analysis of prospective cohort studies suggested that moderate coffee intake was associated with a lower risk of CHD in female drinkers but not in men ${ }^{(10)}$. However, the health-related effects of coffee may not always be in favour of women. Ascherio et al. ${ }^{(11)}$ reported that coffee consumption was associated with reduced mortality from Parkinson's disease in men but not in women due to the interaction between caffeine and use of postmenopausal oestrogens. Therefore, we conducted a meta-analysis of prospective cohort studies to investigate the association of coffee consumption with all-cause mortality and further to elucidate whether this association varied between male and female coffee drinkers.

\section{Methods}

\section{Literature search}

Two investigators (Y.Z. and K.W.) independently performed a literature search in the PubMed and Scopus databases for eligible publications up to November 2013 using the search query: (coffee AND (death OR mortality)). The search was restricted to articles published in English. An additional manual search was also conducted using reference lists from previous meta-analyses and review 
articles. To be included, a study had meet all of the following criteria: (i) prospective cohort design; (ii) evaluate the association of habitual coffee drinking with all-cause mortality in a normal population; (iii) provide adjusted risk estimates with $95 \%$ confidence intervals; and (iv) use non/occasional coffee drinkers as the reference category. Studies carried out in people with hypertension, diabetes, CVD or cancer were not to be taken into consideration. For different articles reporting data from the same population, we selected the article with the largest sample size.

\section{Data extraction}

The following information for each study was extracted by two investigators (Y.Z. and R.Z.) independently: (i) first author's surname; (ii) geographic region where the study was done; (iii) mean follow-up time; (iv) age range and gender of population; (v) total number of subjects and number of death events due to all causes; (vi) coffee intake categories; (vii) corresponding maximally adjusted risk estimates with $95 \%$ confidence intervals; and (viii) confounding variables controlled for. If a study reported outcomes for men and women separately, we separated it as two different cohorts. For dose-response meta-analysis, we also extracted the number of death events and subjects or person-years in each category. If the numbers of death events by levels of coffee intake were not provided directly, we estimated them from the total number of subjects along with the non-adjusted risk estimates or, if not reported, the minimally adjusted risk estimates within each category in that study.

In each category, the median or the mean coffee intake was assigned as the dose of average coffee consumption. If the median or the mean coffee intake was not provided either, the midpoint of the upper and lower boundaries was regarded as the average dose. For an open-ended highest category, the average coffee consumption of the category was set at 1.2 times the lower boundary. If the lower boundary of a lowest category was not available, we assumed the lower boundary was zero.

\section{Statistical analysis}

Heterogeneity among studies was assessed by the $I^{2}$ statistic, which represents the amount of total variability that is attributed to between-study variability ${ }^{(12,13)}$. To facilitate description, we considered that $I^{2}$ values of $<25 \%$, $25-75 \%$ and $>75 \%$ indicated light, moderate and high level of heterogeneity among studies, respectively.

We used relative risk (RR) to express different risk estimates in each study. The natural logarithms of the maximally adjusted relative risk and corresponding $95 \%$ confidence interval in each category were used for pooled analyses. The random-effects model developed by DerSimonian and Laird ${ }^{(14)}$, which provides more conservative results, was employed to calculate the pooled estimates. For categorical meta-analyses we set four coffee intake groups: (i) non/occasional drinkers (the lowest category in each study); (ii) $1-<3$ cups/d; (iii) $3-<5$ cups/d; and (iv) $\geq 5$ cups/d. This classification is similar to the one used in a previous meta-analysis on coffee ${ }^{(15)}$. If multiple categories from the same study were located in a single group, we combined them into one category. We further conducted subgroup analyses stratified by gender, geographic region and degree of adjustment. For the analyses stratified by degree of adjustment, we predefined two models: (i) model A referred to studies providing risk estimates and 95\% confidence intervals adjusted for age, smoking status, alcohol intake and physical activity; and (ii) model $\mathrm{B}$ referred to studies which provided risk estimates and $95 \%$ confidence intervals adjusted for education level, which could reflect the socio-economic status of coffee drinkers, on the basis of model A. Sensitivity analyses were carried out by omitting one study at a time to examine whether the pooled estimates were driven by any single study. Possible publication bias was tested using Egger's linear regression test ${ }^{(16)}$ and Begg's rank correlation test ${ }^{(17)}$.

We further conducted a two-stage random-effects dose-response meta-analysis to evaluate the association between coffee drinking and all-cause mortality. The potential non-linearity was examined by modelling coffee consumption using restricted cubic splines with three knots at fixed percentiles $(10 \%, 50 \%, 90 \%)$ of the coffee intake distribution, as suggested by Harrell ${ }^{(18)}$. A $P$ value for possible non-linearity was obtained by testing the null hypothesis that the regression coefficient of the second spline was equal to zero ${ }^{(19)}$. We adopted generalized least squares models as proposed by Greenland and Longnecker ${ }^{(20)}$ and Orsini et al. ${ }^{(21)}$ to calculate study-specific coefficient estimates and variance/covariance matrix. Then, the two regression coefficients of each study were pooled in the multivariate random-effects meta-regression analysis as described by Jackson et al. ${ }^{(13)}$. Those studies which provided less than three coffee consumption categories, including the reference category, were excluded from the dose-response meta-analyses.

All $P$ values were two-tailed with a significance level of 0.05. All statistical analyses were conducted using the statistical software package Stata/SE $12 \cdot 0$ for Windows.

\section{Results}

\section{Literature search and study characteristics}

Figure 1 presents the flowchart of the literature search. Finally, seventeen eligible studies consisting of 1054571 participants and 131212 death events due to all causes were identified and included in the present study ${ }^{(4-6,8,22-34)}$. The mean follow-up time of each study ranged from $7 \cdot 1$ to 25 years with a median of 15 years. Nine studies ${ }^{(4-6,8,26,27,30,33,34)}$ separately reported outcomes for men and women, hence there were eleven cohorts on men and ten cohorts on women. Of the seventeen studies, eight were conducted in 


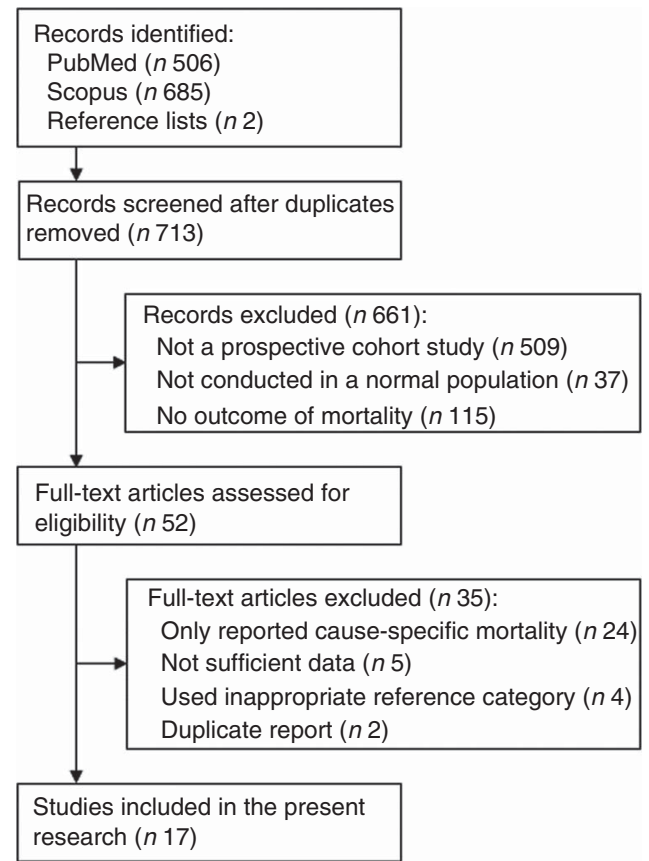

Fig. 1 Flowchart of the literature search

the $\mathrm{USA}^{(4,5,8,23,25,28,29,31)}$, six in Europe ${ }^{(22,24,27,30,32,34)}$ and three in Japan ${ }^{(6,26,34)}$. Twelve studies reported risk estimates with $95 \%$ confidence intervals adjusted for age, smoking status, alcohol intake and physical activity ${ }^{(4-6,8,22-26,31-33)}$ and eight of them additionally controlled for education level ${ }^{(4,8,22-26,33)}$. The characteristics of all included studies are shown in Table 1.

\section{All studies}

When compared with non/occasional coffee drinkers, the pooled RR for all-cause mortality were 0.89 (95\% CI 0.85 , $0.93 ; I^{2}=75 \%$ ) for $1-<3 \mathrm{cups} / \mathrm{d}, 0.87$ (95\% CI 0.83, 0.91; $I^{2}=60 \%$ ) for $3-<5 \mathrm{cups} / \mathrm{d}$ and 0.90 (95\% CI 0.87, 0.94; $\left.I^{2}=19 \%\right)$ for $\geq 5 \mathrm{cups} / \mathrm{d}$. There was considerable betweenstudy heterogeneity in each coffee intake group and relevant forest plots are provided in the online supplementary material. No evidence of publication bias was found (for $1-<3$ cups/d, Begg's $P=0 \cdot 21$, Egger's $P=0.59$; for $3-<5$ cups/d, Begg's $P=0 \cdot 84$, Egger's $P=0 \cdot 80$; for $\geq 5$ cups/d, Begg's $P=0.74$, Egger's $P=0.61$ ). In the sensitivity analyses, omitting studies one by one did not change the significance of any pooled RR. For the coffee consumption group of $1-<3$ cups/d, after excluding Kahn et $a l .{ }^{(28)}$, the heterogeneity among studies that combined men and women together reduced from $76 \%$ to $20 \%$; however, the between-study heterogeneity of all included studies in this coffee intake group was not obviously lowered.

Two studies ${ }^{(32,34)}$ were not incorporated in the doseresponse meta-analysis because of limited numbers of coffee intake categories. We observed a significant nonlinear association $(P$ for non-linearity $<0 \cdot 001$ ) between coffee drinking and all-cause mortality (Fig. 2(a)). A moderate degree of heterogeneity was detected among studyspecific trends derived from the coefficients of the first and second spline transformations: $I^{2}$ first $=69 \%(95 \% \mathrm{CI}$ $53 \%, 80 \%)$ and $I^{2}$ second $=29 \%$ (95\% CI 0\%, $\left.57 \%\right)$. The slope of the dose-response relationship was approximately U-shaped and the maximum protection was reached at 3-4 cups coffee/d.

\section{Men and women}

As one of the main objectives of the present research was to explore whether the association of coffee intake with total mortality differed between men and women, those studies that combined two sexes together were not included in the subgroup analyses ${ }^{(24,25,28,29,31)}$. The results of subgroup analyses are presented in Fig. 3. With regard to male coffee drinkers, the pooled RR for all-cause mortality were $0.91\left(95 \%\right.$ CI $\left.0.84,0.99 ; I^{2}=78 \%\right)$ for $1-<3$ cups/d, 0.90 (95\% CI 0.85, 0.97; $I^{2}=55 \%$ ) for $3-<5 \mathrm{cups} / \mathrm{d}$ and 0.94 (95\% CI $0.84,1.04 ; I^{2}=54 \%$ ) for $\geq 5 \mathrm{cups} / \mathrm{d}$. No evidence of linear trend $(P$ for non-linearity $<0.001$ ) was detected for the association of coffee intake and total mortality in men (Fig. 2(b)) and the heterogeneity among study-specific trends estimates were: $I^{2}{ }_{\text {first }}=62 \%(95 \% \mathrm{CI}$ $25 \%, 81 \%)$ and $I_{\text {second }}^{2} 0 \%(95 \%$ CI $0 \%, 62 \%)$.

In female coffee drinkers, the summarized RR for total mortality were 0.84 (95\% CI $0.80,0.88 ; I^{2}=22 \%$ ) for $1-<3$ cups/d, 0.81 (95\% CI $0.75,0.87 ; I^{2}=39 \%$ ) for $3-<5$ cups/d and 0.85 (95\% CI 0.80, 0.90; $I^{2}=0 \%$ ) for $\geq 5 \mathrm{cups} / \mathrm{d}$ in comparison with non/occasional coffee drinkers (Fig. 3). The slope of the relationship between coffee consumption and total mortality in women was roughly U-shaped ( $P$ for non-linearity $<0 \cdot 001$, Fig. 2(c)) and the maximum reduction in all-cause mortality was observed at 3-5 cups coffee/d. Moderate heterogeneity among trend estimates of relevant studies was found: $I^{2}$ first $=41 \%(95 \%$ CI $0 \%, 73 \%)$ and $I^{2}$ second $=31 \%(95 \%$ CI $0 \%, 68 \%)$.

For men who drunk $\geq 5$ cups coffee/d, there were marginally significant inverse associations of coffee intake with total mortality in studies that reported risk estimates with 95\% confidence intervals adjusted for age, smoking status, alcohol intake and physical activity $(\mathrm{RR}=0.92 ; 95 \%$ CI $0.83,1.00 ; I^{2}=0 \%$; model A, Fig. 3) and in those that additionally controlled for education level $(\mathrm{RR}=0 \cdot 89 ; 95 \%$ CI $0.81,0.98 ; I^{2}=0 \%$; model B, Fig. 3). For men who drunk $1-<3$ cups coffee/d or $3-<5$ cups coffee/d and for female coffee drinkers in all the three coffee consumption groups, the pooled RR and corresponding 95\% CI of allcause mortality remained stable in the subgroup analyses stratified by degree of adjustment (models A and B, Fig. 3). In the subgroup analyses divided by geographical region, there was no evidence of significant inverse associations between habitual coffee drinking and all-cause mortality in all the three coffee consumption groups for male drinkers from the USA or European countries (Fig. 3). However, these results should be interpreted with caution due to the limited numbers of studies. 
Table 1 Characteristics of studies included in the present meta-analysis of coffee drinking and all-cause mortality

\begin{tabular}{|c|c|c|c|c|c|c|c|c|c|c|}
\hline \multirow{2}{*}{$\begin{array}{l}\text { Study; country; mean } \\
\text { duration }\end{array}$} & \multirow{2}{*}{$\begin{array}{l}\text { Gender and sample } \\
\text { size; age (years) }\end{array}$} & \multirow[b]{2}{*}{ No. of cases } & \multirow{2}{*}{$\begin{array}{l}\text { Coffee intake } \\
\text { categories }\end{array}$} & \multicolumn{2}{|c|}{ Men } & \multicolumn{2}{|c|}{ Women } & \multicolumn{2}{|c|}{ Mixed } & \multirow[b]{2}{*}{ Confounding factors adjusted for } \\
\hline & & & & $\mathrm{RR}$ & $95 \% \mathrm{Cl}$ & $\mathrm{RR}$ & $95 \% \mathrm{Cl}$ & $\mathrm{RR}$ & $95 \% \mathrm{Cl}$ & \\
\hline $\begin{array}{l}\text { Ahmed et al. } \\
\text { Sweden } \\
9 \text { years }\end{array}$ & $\begin{array}{l}\text { M: } n 37315 \\
45-79\end{array}$ & M: $n 784$ & $\begin{array}{l}<1 \mathrm{cup} / \mathrm{d} \\
2 \mathrm{cups} / \mathrm{d} \\
3 \mathrm{cups} / \mathrm{d} \\
4 \mathrm{cups} / \mathrm{d} \\
\geq 5 \mathrm{cups} / \mathrm{d}\end{array}$ & $\begin{array}{l}1.00 \\
0.86 \\
0.83 \\
0.84 \\
0.87\end{array}$ & $\begin{array}{c}\text { Ref. } \\
0.77,0.96 \\
0.74,0.92 \\
0.74,0.94 \\
0.78,0.98\end{array}$ & $\begin{array}{l}- \\
- \\
- \\
- \\
-\end{array}$ & $\begin{array}{l}- \\
- \\
- \\
- \\
-\end{array}$ & $\begin{array}{l}- \\
\overline{-} \\
- \\
- \\
-\end{array}$ & $\begin{array}{l}- \\
- \\
- \\
-\end{array}$ & $\begin{array}{l}\text { Age, BMl, activity score, smoking, history } \\
\text { of hypercholesterolaemia, family history } \\
\text { of Ml before age } 60 \text {, education, marital } \\
\text { status, aspirin use, alcohol intake, tea, } \\
\text { energy-adjusted fat intake, Na intake }\end{array}$ \\
\hline $\begin{array}{l}\text { Andersen et al. } \\
\text { USA } \\
15 \text { years }\end{array}$ & $\begin{array}{l}\text { W: } n 27312 \\
55-69\end{array}$ & W: $n 4265$ & $\begin{array}{l}\text { Never } \\
<1 \text { cup/d } \\
1-3 \text { cups/d } \\
4-5 \text { cups/d } \\
\geq 6 \text { cups/d }\end{array}$ & $\begin{array}{l}- \\
- \\
- \\
- \\
-\end{array}$ & $\begin{array}{l}- \\
- \\
- \\
- \\
-\end{array}$ & $\begin{array}{l}1.00 \\
0.91 \\
0.85 \\
0.81 \\
0.87\end{array}$ & $\begin{array}{c}\text { Ref. } \\
0.80,1.04 \\
0.76,0.94 \\
0.72,0.91 \\
0.76,1.00\end{array}$ & $\begin{array}{l}- \\
- \\
- \\
- \\
-\end{array}$ & $\begin{array}{l}- \\
- \\
- \\
- \\
-\end{array}$ & $\begin{array}{l}\text { Age, smoking, alcohol, BMI, WHR, } \\
\text { education, physical activity, use of } \\
\text { oestrogens, use of multivitamin } \\
\text { supplements, energy intake and diet }\end{array}$ \\
\hline $\begin{array}{l}\text { de Koning Gans } \\
\text { et al. } 24) \\
\text { Netherlands } \\
13 \text { years }\end{array}$ & $\begin{array}{l}\text { Mixed: } n 37514 \\
50-69\end{array}$ & n 1405 & $\begin{array}{l}<1 \text { cup/d } \\
1-3 \mathrm{cups} / \mathrm{d} \\
3 \cdot 1-6 \mathrm{cups} / \mathrm{d} \\
>6 \text { cups } / \mathrm{d}\end{array}$ & $\begin{array}{l}- \\
- \\
- \\
-\end{array}$ & $\begin{array}{l}- \\
- \\
- \\
-\end{array}$ & $\begin{array}{l}- \\
- \\
- \\
-\end{array}$ & $\begin{array}{l}- \\
- \\
- \\
-\end{array}$ & $\begin{array}{l}1.00 \\
0.93 \\
0.89 \\
0.93\end{array}$ & $\begin{array}{c}\text { Ref. } \\
0.79,1.09 \\
0.77,1.04 \\
0.76,1.15\end{array}$ & $\begin{array}{l}\text { Age, sex, education, physical activity, } \\
\text { smoking, waist circumference, } \\
\text { menopausal status, alcohol intake, tea } \\
\text { intake, total energy, saturated fat, fibre, } \\
\text { vitamin C }\end{array}$ \\
\hline $\begin{array}{l}\text { Freedman et al. }{ }^{(4)} \\
\text { USA } \\
14 \text { years }\end{array}$ & $\begin{array}{l}\text { M: } n 229119 \\
\text { W: } n 173141 \\
\text { 50-71 }\end{array}$ & $\begin{array}{l}\text { M: } n 33731 \\
\text { W: } n 18784\end{array}$ & $\begin{array}{l}\text { Never } \\
<1 \text { cup/d } \\
1 \text { cup/d } \\
2 \text { or } 3 \text { cups/d } \\
4 \text { or } 5 \text { cups/d } \\
\geq 6 \text { cups } / \mathrm{d}\end{array}$ & $\begin{array}{l}1.00 \\
0.99 \\
0.94 \\
0.90 \\
0.88 \\
0.90\end{array}$ & $\begin{array}{c}\text { Ref. } \\
0.95,1.04 \\
0.90,0.99 \\
0.86,0.93 \\
0.84,0.93 \\
0.85,0.96\end{array}$ & $\begin{array}{l}1.00 \\
1.01 \\
0.95 \\
0.87 \\
0.84 \\
0.85\end{array}$ & $\begin{array}{c}\text { Ref. } \\
0.96,1.07 \\
0.90,1.01 \\
0.83,0.92 \\
0.79,0.90 \\
0.78,0.93\end{array}$ & $\begin{array}{l}- \\
- \\
- \\
- \\
- \\
-\end{array}$ & $\begin{array}{l}- \\
- \\
- \\
- \\
-\end{array}$ & $\begin{array}{l}\text { Age, BMI, race, education, alcohol intake, } \\
\text { smoking status, health status, marital } \\
\text { status, physical activity, total energy } \\
\text { intake, dietary intake, use of vitamin } \\
\text { supplements, use of postmenopausal } \\
\text { hormone therapy }\end{array}$ \\
\hline $\begin{array}{l}\text { Gardener et al. }^{(25)} \\
\text { USA } \\
13 \text { years }\end{array}$ & $\begin{array}{l}\text { Mixed: } n 2461 \\
68 \cdot 30 \text { (sD 10.23) }\end{array}$ & 863 & $\begin{array}{l}<1 \text { cup/month } \\
1 \text { cup } / \text { month-4 } \\
\quad \text { cups/week } \\
5-7 \text { cups/week } \\
2-3 \text { cups/d } \\
\geq 4 \text { cups } / \text { d }\end{array}$ & $\begin{array}{l}- \\
- \\
-\end{array}$ & $\begin{array}{l}- \\
- \\
-\end{array}$ & $\begin{array}{l}- \\
- \\
-\end{array}$ & $\begin{array}{l}- \\
- \\
- \\
- \\
-\end{array}$ & $\begin{array}{l}1.00 \\
0.77 \\
\\
0.94 \\
0.94 \\
0.68\end{array}$ & $\begin{array}{c}\text { Ref. } \\
0.61,0.98 \\
\\
0.78,1.12 \\
0.75,1.17 \\
0.44,1.05\end{array}$ & $\begin{array}{l}\text { Age, sex, race, education, smoking status, } \\
\text { alcohol intake, physical activity, diet, } \\
\text { BMI, history of CVD, diabetes, } \\
\text { hypertension, hypercholesterolaemia, } \\
\text { other non-water beverage consumption, } \\
\text { milk and cream in coffee, non-dairy } \\
\text { creamer in coffee }\end{array}$ \\
\hline $\begin{array}{l}\text { Iwai et al. } \\
\text { Japan } \\
9.9 \text { years }\end{array}$ & $\begin{array}{l}\text { M: } n 1404 \\
\text { W: } n 1451 \\
40-79\end{array}$ & $\begin{array}{l}\text { M: } n 246 \\
\text { W: } n 115\end{array}$ & $\begin{array}{l}<0.5 \mathrm{cup} / \mathrm{d} \\
0.5-1 \mathrm{cup} / \mathrm{d} \\
\geq 2 \mathrm{cups} / \mathrm{d}\end{array}$ & $\begin{array}{l}1.00 \\
0.70 \\
0.40\end{array}$ & $\begin{array}{l}\text { Ref. } \\
0.52,0.94 \\
0.30,0.63\end{array}$ & $\begin{array}{l}1.00 \\
0.70 \\
0.76\end{array}$ & $\begin{array}{c}\text { Ref. } \\
0.45,1.09 \\
0.45,1.27\end{array}$ & $\begin{array}{l}- \\
- \\
-\end{array}$ & $\begin{array}{l}- \\
- \\
-\end{array}$ & $\begin{array}{l}\text { Age, physical activity, history of heart } \\
\text { diseases, education, smoking status, } \\
\text { alcohol intake }\end{array}$ \\
\hline $\begin{array}{l}\text { Jazbec et al. } \\
\text { Croatia } \\
11 \text { years }\end{array}$ & $\begin{array}{l}\text { M: } n 1561 \\
\text { W: } n 1776 \\
35-59\end{array}$ & $\begin{array}{l}\text { M: } n 568 \\
\text { W: } n 382\end{array}$ & $\begin{array}{l}\text { Never } \\
\text { Sometimes } \\
1-2 \text { cups/d } \\
\geq 2 \text { cups } / d\end{array}$ & $\begin{array}{l}1.00 \\
0.82 \\
0.78 \\
0.73\end{array}$ & $\begin{array}{c}\text { Ref. } \\
0.65,1.03 \\
0.61,0.98 \\
0.53,1.00\end{array}$ & $\begin{array}{l}1.00 \\
0.89 \\
0.63 \\
0.66\end{array}$ & $\begin{array}{c}\text { Ref. } \\
0.65,1.21 \\
0.46,0.86 \\
0.43,1.02\end{array}$ & $\begin{array}{l}- \\
- \\
-\end{array}$ & $\begin{array}{l}- \\
- \\
-\end{array}$ & $\begin{array}{l}\text { Age, region, smoking status, DBP, feeling } \\
\text { of well-being, history of stomach ulcer }\end{array}$ \\
\hline $\begin{array}{l}\text { Kahn et al. } \\
\text { USA } \\
21 \text { years }\end{array}$ & $\begin{array}{l}\text { Mixed: } n 20969 \\
>30\end{array}$ & $n 5654$ & $\begin{array}{l}<1 \text { cup } / \mathrm{d} \\
1-2 \mathrm{cups} / \mathrm{d} \\
\geq 3 \mathrm{cups} / \mathrm{d}\end{array}$ & $\begin{array}{l}- \\
- \\
-\end{array}$ & $\begin{array}{l}- \\
- \\
-\end{array}$ & $\begin{array}{l}- \\
- \\
-\end{array}$ & $\begin{array}{l}- \\
- \\
-\end{array}$ & $\begin{array}{l}1.00 \\
1.21 \\
1.26\end{array}$ & $\begin{array}{c}\text { Ref. } \\
1.06,1.39 \\
1.05,1.51\end{array}$ & $\begin{array}{l}\text { Age, history of CVD, hypertension, } \\
\text { diabetes, or cancer, age at initial } \\
\text { exposure to Adventist Church, smoking } \\
\text { status }\end{array}$ \\
\hline $\begin{array}{l}\text { Klatsky et al. } \\
\text { USA } \\
21 \text { years }\end{array}$ & $\begin{array}{l}\text { Mixed: } n 128934 \\
\text { Mean: } 46\end{array}$ & $n 4501$ & $\begin{array}{l}\text { Never } \\
<1 \text { cup/d } \\
1-3 \text { cups/d } \\
4-6 \text { cups/d } \\
>6 \text { cups } / d\end{array}$ & $\begin{array}{l}- \\
- \\
- \\
- \\
-\end{array}$ & $\begin{array}{l}- \\
- \\
- \\
- \\
-\end{array}$ & $\begin{array}{l}- \\
- \\
- \\
- \\
-\end{array}$ & $\begin{array}{l}- \\
- \\
\overline{-} \\
- \\
-\end{array}$ & $\begin{array}{l}1.00 \\
0.96 \\
0.94 \\
0.93 \\
0.88\end{array}$ & $\begin{array}{c}\text { Ref. } \\
0.85,1.07 \\
0.86,1.02 \\
0.83,1.04 \\
0.76,1.02\end{array}$ & $\begin{array}{l}\text { Age, sex, race, BMI, smoking status, } \\
\text { alcohol drinking, education, marital } \\
\text { status }\end{array}$ \\
\hline
\end{tabular}




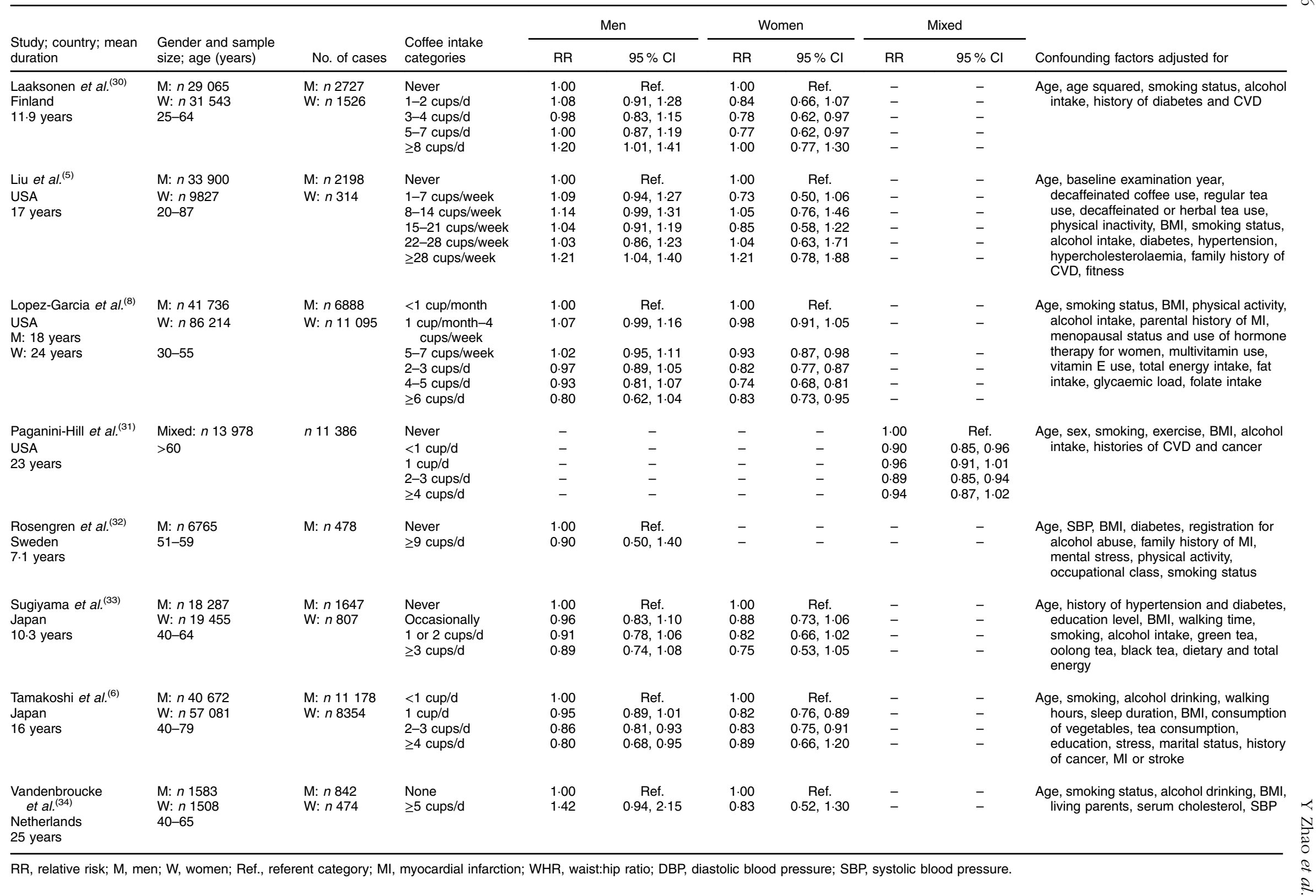


(a)

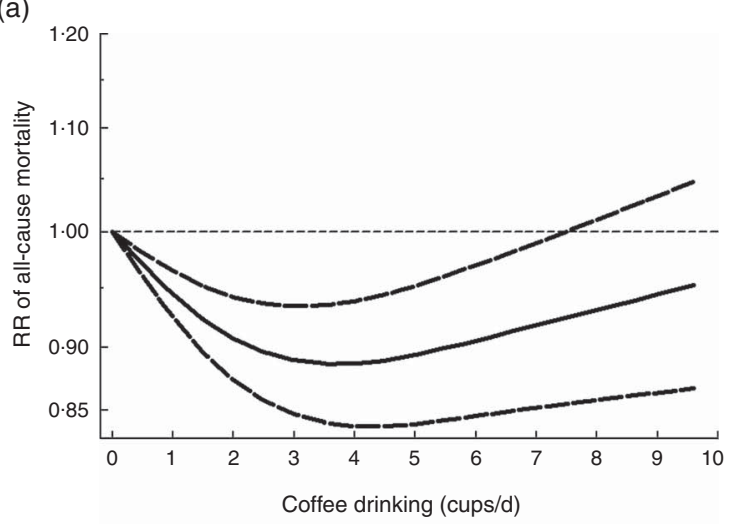

(b)
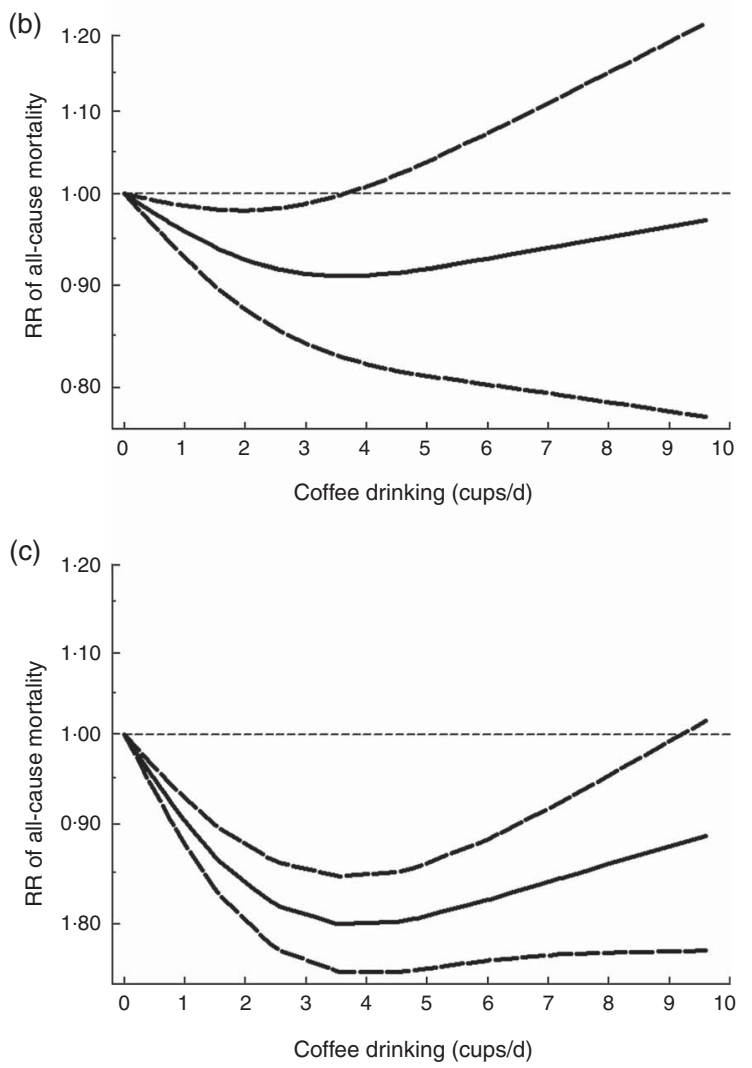

Fig. 2 The non-linear association of habitual coffee drinking with all-cause mortality: (a) all studies $(P$ for non-linearity $<0.001)$; (b) cohorts of men only $(P$ for non-linearity $<0.001)$; (c) cohorts of women only ( $P$ for non-linearity $<0.001)$. relative risk $(\mathrm{RR}) ;-\ldots-, 95 \%$ confidence intervals; $-\ldots$ null effect. The results were gained from the two-stage randomeffects dose-response meta-analyses

\section{Discussion}

The present research did not support the hypothesis that habitual coffee consumption increased the risk of death from all causes, whereas light to moderate coffee drinking was inversely associated with all-cause mortality especially for female drinkers. The significant reduction in total mortality was attenuated in those who drunk large quantities of coffee for both men and women.
Natella et $a l .{ }^{(35)}$ found that one cup of coffee daily helped to incorporate phenolic acids into LDL and increased the resistance of LDL to ex vivo oxidation in healthy individuals. Meta-analyses of prospective cohort studies have suggested U-shaped associations between coffee drinking and the incidence of stroke ${ }^{(15)}$, congestive heart failure ${ }^{(36)}$ and Parkinson's disease ${ }^{(37)}$, with the maximum and also statistically significant protection observed in people who drunk three to four cups of coffee daily in all cases. Despite case-control and cohort studies having reported inconclusive results about the relationship between coffee intake and $\mathrm{CHD}^{(10)}$, it is plausible that the inverse association between light to moderate coffee consumption and all-cause mortality may be partially attributed to the protection against certain kinds of cardiovascular and cerebrovascular diseases. The associations of moderate coffee consumption with the incidence and mortality of cancer varied by body sites and low to moderate coffee consumption was inversely related to total cancer incidence ${ }^{(38)}$. Whether there is a reverse causality between light to moderate coffee drinking and reduced all-cause mortality requires further investigation.

For both men and women, the reduction in total mortality was attenuated in those who drunk large quantities of coffee. Excessive intake of coffee could neutralize its benefits and even impose unfavourable effects on the human body. In healthy individuals, heavy consumption of either filtered coffee or unfiltered coffee could give rise to substantially elevated plasma concentrations of total homocysteine ${ }^{(39,40)}$. Olthof et al. ${ }^{(41)}$ assumed that the homocysteine-elevating effect was possibly caused by the chlorogenic acid in coffee. For hypertensive individuals, excessive coffee intake could produce an acute increase in blood pressure and thus could raise the blood pressure above a safe level, but no evidence was found to support an appreciable association between habitual coffee consumption and a higher risk of CVD in hypertensive individuals $^{(42)}$. Cafestol and kahweol contained in coffee beans are regarded as cholesterol-raising factors and it is well documented that unfiltered coffee can dosedependently increase serum concentrations of total and LDL cholesterol ${ }^{(43)}$. Correa et al. ${ }^{(44)}$ further found that daily consumption of four cups of paper-filtered coffee, from which cafestol and kahweol had been removed, could also have an undesirable effect on plasma cholesterol and inflammation profile in healthy individuals independent of its antioxidant status. Moreover, coffee consumption tended to impair the therapeutic effects of some cardioprotective drugs like statins ${ }^{(45)}$. Therefore, consuming too much coffee should not be recommended in view of keeping healthy.

The present research suggested that female drinkers were more predisposed to the health-promoting effect of coffee than male drinkers. In subgroup analyses stratified by the degree of adjustment for confounding factors, the 

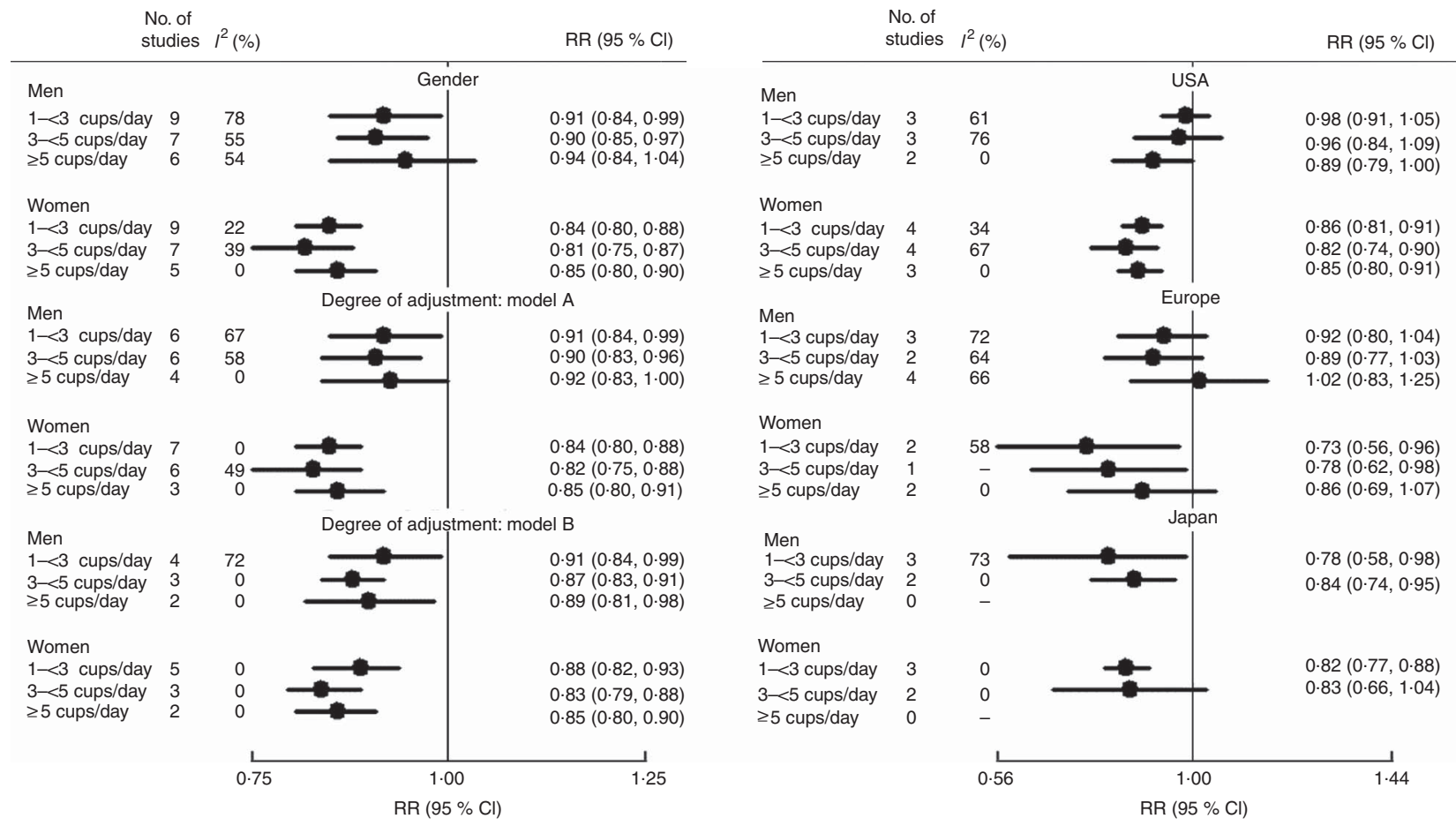

Fig. 3 Subgroup analyses of the association between habitual coffee drinking and all-cause mortality, showing pooled relative risks (RR; $\square$ ) and $95 \%$ confidence intervals (represented by horizontal bars) from categorical meta-analyses using a random-effects model. Model A, studies providing risk estimates and $95 \% \mathrm{Cl}$ adjusted for age, smoking status, alcohol intake and physical activity; model B, studies providing risk estimates and $95 \% \mathrm{Cl}$ additionally adjusted for education level

gender-specific associations remained unchanged. Results from observational studies suggest that sex hormone status and the activity of cytochrome P450 1A2 enzyme (CYP1A2) could possibly be responsible for the modifying role of gender. As the major biologically active component in coffee, caffeine is predominantly metabolized by CYP1A2 in the liver. Women, because of higher oestradiol concentrations, generally have lower activity of CYP1A2 than men ${ }^{(46,47)}$. Lowcock et al. ${ }^{(48)}$ hypothesized that there could be a greater protective effect of coffee among individuals who metabolize caffeine slowly than among fast metabolizers due to a theoretically extended duration of caffeine exposure. Results from Hallstrom et al. ${ }^{(49)}$ indicated that excessive consumption of coffee was associated with lower bone mineral density in elderly men, but not in women, and bone mineral density was lower in high consumers of coffee with rapid metabolism of caffeine. A meta-analysis of prospective cohort studies indicated that habitual moderate coffee drinking was also related to a lower risk of $\mathrm{CHD}$ in female coffee drinkers rather than male drinkers ${ }^{(10)}$. To date, randomized controlled trials aimed at exploring the coffee-gender interaction are limited. One clinical trial by Gavrieli et al. ${ }^{(50)}$ found that two to four cups of coffee daily induced a lower increase of postprandial insulin concentrations in men than in women. However, results from a randomized controlled trial suggested that the effect of caffeine on blood pressure and heart rate did not vary by sex or hormonal status in healthy individuals ${ }^{(51)}$. Yet, the underlying mechanism of the observed variation between men and women in the association of coffee with total mortality remains to be established.

A Scottish study revealed that coffee drinkers were younger, healthier and had higher income than tea drinkers ${ }^{(52)}$. Nevertheless, the links between coffee drinking habits and health consciousness may vary from person to person and from region to region. An array of prospective cohort studies $^{(4-6,8,23)}$ have reported for both men and women that heavy coffee drinkers were likely to smoke more cigarettes, consume more alcoholic beverages and do less physical exercise. Mukamal et al. ${ }^{(53)}$ reported that coffee drinkers tended to be free of co-morbidity but were more likely to be frequent smokers in a population who had survived acute myocardial infraction. In the present study, after pooling studies that controlled for smoking status, alcohol intake and physical activity, the association of coffee consumption and total mortality in either men or women was not significantly altered. However, for individual coffee drinkers, particularly those with less health consciousness, unhealthy dietary and lifestyle factors could offset the beneficial effect of coffee to a large extent.

The present results were not in complete agreement with those from two previous quantitative reviews ${ }^{(54,55)}$ which reported only the favourable association of coffee intake with total mortality and claimed no difference between male and female coffee drinkers. This discordance possibly stems 
from differences in the included studies and in the methods of data processing. Compared with these two studies, we have set more rigorous selection criteria whereby eligible studies had to include non/occasional coffee drinkers as the reference category and provide adjusted risk estimates. We further incorporated two up-to-date large prospective cohort studies $^{(6,25)}$. Besides, both of the two previous studies used data from extreme exposure categories only, which may lower the statistical validity and introduce heterogeneity as suggested by $\mathrm{Yu}$ et $a l .{ }^{(56)}$. We believe that the present study could provide more comprehensive and profound insights into the association of habitual coffee drinking with total mortality and bring about meaningful implications for future studies concerning the health-related effect of coffee consumption.

Some limitations of the present study should be put forward. First, most included studies did not report the coffee preparation methods and combined caffeinated and decaffeinated coffee together. The composition of a cup of coffee depends largely on the preparing method. We did not conduct subgroup analyses stratified by coffee type since only four of the seventeen studies ${ }^{(4,8,25,31)}$ have reported separately the relationship of different types of coffee (caffeinated and decaffeinated coffee) with all-cause mortality. Muley et al. ${ }^{(57)}$ have suggested advantages of filtered coffee over boiled coffee and of decaffeinated coffee over caffeinated coffee in the association with the risk of type 2 diabetes. Decaffeinated coffee was also associated with a small reduction in all-cause mortality, but no substantial difference between caffeinated coffee and decaffeinated coffee in the relationship with total mortality was noted $^{(4,8)}$. Decaffeinated coffee could be a good option for those who experience uncomfortable effects from caffeine stimulation. One survey in the USA showed that only about $10 \%$ people inclusively consume decaffeinated coffee and its use was related to illness in some people but to a healthy lifestyle in others ${ }^{(58)}$. Besides, filtered coffee has been proved to be less cholesterol-raising than unfiltered coffee ${ }^{(43)}$. Unfortunately, information about the preparing methods were absent in most included studies, thus bringing about great difficulties for us to deal with the heterogeneity across the included studies.

Second, the observed association of coffee drinking with all-cause mortality could be biased by unmeasured or unknown potential confounding factors or alternative explanations, notwithstanding that most of the included studies have controlled for major confounders such as age and smoking status, alcohol intake and physical activity.

Third, most included studies only assessed the frequency of coffee intake at baseline by self-report. People who developed hypertension or other risk factors of CVD during the follow-up period may change their drinking habits. Besides, recall bias and misclassification of coffee consumption also imposed unfavourable impacts on the interpretation of the association between coffee drinking and all-cause mortality.

\section{Conclusion}

In summary, it is important to take into account both the advantages and disadvantages of coffee consumption. Although association cannot prove causation, light to moderate coffee drinking may indeed help to decrease the risk of death from all causes, particularly in female drinkers.

\section{Acknowledgements}

Financial support: This study was funded by the National Natural Science Foundation of China (NSFC; grant number 81273054). NSFC had no role in the design, analysis or writing of this article. Conflict of interest: None. Authorship: Y.Z. designed the study, conducted the literature search and data extraction, analysed the data and wrote the manuscript; K.W. conducted the literature search and analysed the data; J.Z. analysed the data and critically reviewed the manuscript; R.Z. conducted the data extraction and wrote the manuscript; D.L. designed the study and critically reviewed the manuscript. Ethics of human subject participation: Ethical approval was not needed.

\section{Supplementary material}

To view supplementary material for this article, please visit http://dx.doi.org/10.1017/S1368980014001438

\section{References}

1. Van Dam RM \& Hu FB (2005) Coffee consumption and risk of type 2 diabetes. JAMA 294, 97-104.

2. Lai GY, Weinstein SJ, Albanes D et al. (2013) The association of coffee intake with liver cancer incidence and chronic liver disease mortality in male smokers. Br J Cancer 109, 1344-1351.

3. Misik M, Hoelzl C, Wagner KH et al. (2010) Impact of paper filtered coffee on oxidative DNA-damage: results of a clinical trial. Mutat Res 692, 42-48.

4. Freedman ND, Park Y, Abnet CC et al. (2012) Association of coffee drinking with total and cause-specific mortality. N Engl J Med 366, 1891-1904.

5. Liu J, Sui X, Lavie CJ et al. (2013) Association of coffee consumption with all-cause and cardiovascular disease mortality. Mayo Clin Proc 88, 1066-1074.

6. Tamakoshi A, Lin Y, Kawado M et al. (2011) Effect of coffee consumption on all-cause and total cancer mortality: findings from the JACC study. Eur J Epidemiol 26, 285-293.

7. O'Keefe JH, Bhatti SK, Patil HR et al. (2013) Effects of habitual coffee consumption on cardiometabolic disease, cardiovascular health, and all-cause mortality. J Am Coll Cardiol 62, 1043-1051.

8. Lopez-Garcia E, van Dam RM, Li TY et al. (2008) The relationship of coffee consumption with mortality. Ann Intern Med 148, 904-914.

9. Kleemola P, Jousilahti P, Pietinen P et al. (2000) Coffee consumption and the risk of coronary heart disease and death. Arch Intern Med 160, 3393-3400. 
10. Wu J, Ho SC, Zhou C et al. (2009) Coffee consumption and risk of coronary heart diseases: a meta-analysis of 21 prospective cohort studies. Int J Cardiol 137, 216-225.

11. Ascherio A, Zhang SM, Hernán MA et al. (2001) Prospective study of caffeine consumption and risk of Parkinson's disease in men and women. Ann Neurol 50, 56-63.

12. Higgins J \& Thompson SG (2002) Quantifying heterogeneity in a meta-analysis. Stat Med 21, 1539-1558.

13. Jackson D, White IR \& Thompson SG (2010) Extending DerSimonian and Laird's methodology to perform multivariate random effects meta-analyses. Stat Med 29, 1282-1297.

14. DerSimonian R \& Laird N (1986) Meta-analysis in clinical trials. Control Clin Trials 7, 177-188.

15. Larsson SC \& Orsini N (2011) Coffee consumption and risk of stroke: a dose-response meta-analysis of prospective studies. Am J Epidemiol 174, 993-1001.

16. Egger M, Smith GD, Schneider M et al. (1997) Bias in metaanalysis detected by a simple, graphical test. $B M J \mathbf{3 1 5}$, 629-634.

17. Begg CB \& Mazumdar M (1994) Operating characteristics of a rank correlation test for publication bias. Biometrics $\mathbf{3 1 5}$, 1088-1101.

18. Harrell FE (2001) Regression Modeling Strategies: With Applications to Linear Models, Logistic Regression, and Survival Analysis. New York: Springer.

19. Orsini N, Li R, Wolk A et al. (2012) Meta-analysis for linear and nonlinear dose-response relations: examples, an evaluation of approximations, and software. Am J Epidemiol 175, 66-73.

20. Greenland S \& Longnecker MP (1992) Methods for trend estimation from summarized dose-response data, with applications to meta-analysis. Am J Epidemiol 135, 1301-1309.

21. Orsini N, Bellocco R \& Greenland S (2006) Generalized least squares for trend estimation of summarized doseresponse data. Stata J 6, 40-57.

22. Ahmed HN, Levitan EB, Wolk A et al. (2009) Coffee consumption and risk of heart failure in men: an analysis from the Cohort of Swedish Men. Am Heart J 158, 667-672.

23. Andersen LF, Jacobs DR, Carlsen MH et al. (2006) Consumption of coffee is associated with reduced risk of death attributed to inflammatory and cardiovascular diseases in the Iowa Women's Health Study. Am J Clin Nutr 83, 1039-1046.

24. de Koning Gans JM, Uiterwaal CS, van der Schouw YT et al. (2010) Tea and coffee consumption and cardiovascular morbidity and mortality. Arterioscler Thromb Vasc Biol 30, $1665-1671$.

25. Gardener H, Rundek T, Wright CB et al. (2013) Coffee and tea consumption are inversely associated with mortality in a multiethnic urban population. J Nutr 143, 1299-1308.

26. Iwai N, Ohshiro H, Kurozawa Y et al. (2002) Relationship between coffee and green tea consumption and all-cause mortality in a cohort of a rural Japanese population. J Epidemiol 12, 191-198.

27. Jazbec A, Simic D, Corovic N et al. (2011) Impact of coffee and other selected factors on general mortality and mortality due to cardiovascular disease in Croatia.J Health Popul Nutr 21, 332-340.

28. Kahn HA, Phillips RL, Snowdon DA et al. (1984) Association between reported diet and all-cause mortality. Twenty-oneyear follow-up on 27530 adult Seventh-Day Adventists. Am J Epidemiol 119, 775-787.

29. Klatsky AL, Armstrong MA \& Friedman GD (1993) Coffee, tea, and mortality. Ann Epidemiol 3, 375-381.

30. Laaksonen M, Talala K, Martelin T et al. (2008) Health behaviours as explanations for educational level differences in cardiovascular and all-cause mortality: a follow-up of 60000 men and women over 23 years. Eur J Public Health 18, 38-43.
31. Paganini-Hill A, Kawas CH \& Corrada MM (2007) Nonalcoholic beverage and caffeine consumption and mortality: the Leisure World Cohort Study. Prev Med 44, 305-310.

32. Rosengren A \& Wilhelmsen L (1991) Coffee, coronary heart disease and mortality in middle-aged Swedish men: findings from the Primary Prevention Study. J Intern Med 230, 67-71.

33. Sugiyama K, Kuriyama S, Akhter M et al. (2010) Coffee consumption and mortality due to all causes, cardiovascular disease, and cancer in Japanese women. J Nutr 140, 1007-1013.

34. Vandenbroucke JP, Kok FJ, van T BG et al. (1986) Coffee drinking and mortality in a 25 -year follow up. Am J Epidemiol 123, 359-361.

35. Natella F, Nardini M, Belelli F et al. (2007) Coffee drinking induces incorporation of phenolic acids into LDL and increases the resistance of LDL to ex vivo oxidation in humans. Am J Clin Nutr 86, 604-609.

36. Mostofsky E, Rice MS, Levitan EB et al. (2012) Habitual coffee consumption and risk of heart failure: a doseresponse meta-analysis. Circ Heart Fail 5, 401-405.

37. Hernan MA, Takkouche B, Caamano Isorna F et al. (2002) A meta-analysis of coffee drinking, cigarette smoking, and the risk of Parkinson's disease. Ann Neurol 52, 276-284.

38. Yu X, Bao Z, Zou J et al. (2011) Coffee consumption and risk of cancers: a meta-analysis of cohort studies. $B M C$ Cancer 11, 96-102.

39. Urgert R, van Vliet T, Zock PL et al. (2000) Heavy coffee consumption and plasma homocysteine: a randomized controlled trial in healthy volunteers. Am J Clin Nutr $\mathbf{7 2}$, 1107-1110.

40. Grubben MJ, Boers GH, Blom HJ et al. (2000) Unfiltered coffee increases plasma homocysteine concentrations in healthy volunteers: a randomized trial. Am J Clin Nutr $\mathbf{7 1}$, 480-484.

41. Olthof MR, Hollman PC, Zock PL et al. (2001) Consumption of high doses of chlorogenic acid, present in coffee, or of black tea increases plasma total homocysteine concentrations in humans. Am J Clin Nutr 73, 532-538.

42. Mesas AE, Leon-Munoz LM, Rodriguez-Artalejo $\mathrm{F}$ et al. (2011) The effect of coffee on blood pressure and cardiovascular disease in hypertensive individuals: a systematic review and meta-analysis. Am J Clin Nutr 94, 1113-1126.

43. Jee SH, He J, Appel LJ et al. (2001) Coffee consumption and serum lipids: a meta-analysis of randomized controlled clinical trials. Am J Epidemiol 153, 353-362.

44. Corrêa TA, Rogero MM, Mioto BM et al. (2013) Paperfiltered coffee increases cholesterol and inflammation biomarkers independent of roasting degree: a clinical trial. Nutrition 29, 977-981.

45. Ye Y, Said GHA, Lin Y et al. (2008) Caffeinated coffee blunts the myocardial protective effects of statins against ischemiareperfusion injury in the rat. Cardiovasc Drugs Ther 22, 275-282.

46. Gunes A \& Dahl M (2008) Variation in CYP1A2 activity and its clinical implications: influence of environmental factors and genetic polymorphisms. Pharmacogenomics $\mathbf{9}$, 625-637.

47. Steege JF, Rupp SL \& Kuhn CM (1992) Menstrual cycle effects on caffeine elimination in the human female. Eur $J$ Clin Pharmacol 43, 543-546.

48. Lowcock EC, Cotterchio M, Anderson LN et al. (2013) High coffee intake, but not caffeine, is associated with reduced estrogen receptor negative and postmenopausal breast cancer risk with no effect modification by CYP1A2 genotype. Nutr Cancer 65, 398-409.

49. Hallstrom H, Melhus H, Glynn A et al. (2010) Coffee consumption and CYP1A2 genotype in relation to bone mineral density of the proximal femur in elderly men and women: a cohort study. Nutr Metab (Lond) 7, 12-20. 
50. Gavrieli A, Fragopoulou E, Mantzoros CS et al. (2013) Gender and body mass index modify the effect of increasing amounts of caffeinated coffee on postprandial glucose and insulin concentrations; a randomized, controlled, clinical trial. Metabolism 8, 1099-1106.

51. Farag NH, Whitsett TL, Mckey BS et al. (2010) Caffeine and blood pressure response: sex, age, and hormonal status. $J$ Womens Health (Larchmt) 19, 1171-1176.

52. Woodward M \& Tunstall-Pedoe H (1999) Coffee and tea consumption in the Scottish Heart Health Study follow up: conflicting relations with coronary risk factors, coronary disease, and all cause mortality. J Epidemiol Community Health 53, 481-487.

53. Mukamal KJ, Maclure M, Muller JE et al. (2004) Caffeinated coffee consumption and mortality after acute myocardial infarction. Am Heart J 147, 999-1004.
54. Malerba S, Turati F, Galeone C et al. (2013) A meta-analysis of prospective studies of coffee consumption and mortality for all causes, cancers and cardiovascular diseases. Eur J Epidemiol 28, 527-539.

55. Je Y \& Giovannucci E (2013) Coffee consumption and total mortality: a meta-analysis of twenty prospective cohort studies. Br J Nutr 111, 1162-1173.

56. Yu WW, Schmid CH, Lichtenstein AH et al. (2013) Empirical evaluation of meta-analytic approaches for nutrient and health outcome dose-response data. Res Synth Methods 3, 256-268.

57. Muley A, Muley P \& Shah M (2012) Coffee to reduce risk of type 2 diabetes? A systematic review. Curr Diabetes Rev 8, 162-168.

58. Shlonsky AK, Klatsky AL \& Armstrong MA (2003) Traits of persons who drink decaffeinated coffee. Ann Epidemiol 13, 273-279. 